\title{
Tata Cara Penyuratan Dan Pendaftaran Awig-Awig Desa Adat Di Bali (Dari Desa Mawacara Ke Bali Mawacara)
}

\author{
I Putu Sastra Wibawa ${ }^{1}$, I Putu Gelgel ${ }^{2}$, dan I Wayan Martha ${ }^{3}$
}

${ }^{1}$ Fakultas Hukum, Universitas Hindu Indonesia, Jalang Sangalangit, Tembau, Denpasar

${ }^{2}$ Fakultas Hukum, Universitas Hindu Indonesia, Jalang Sangalangit, Tembau, Denpasar

${ }^{3}$ Fakultas Hukum, Universitas Hindu Indonesia, Jalang Sangalangit, Tembau, Denpasar

${ }^{1}$ sastra@unhi.ac.id

Saat ini terkait dengan salah satu dari hak tradisional desa adat di Bali dalam mengurus rumah tangganya sendiri melalui hak untuk membentuk aturan hukum adat sebutan lainnya di Bali disebut awig-awig desa adat terjadi pergeseran akibat diterbitkannya Peraturan Daerah Provinsi Bali Nomor 4 Tahun 2019 Tentang Desa Adat di Bali. Pergeseran dimaksud disini, dari awalnya pembentukan awig-awig desa adat berdasarkan tata cara kebiasaan masing-masing desa adat (desa mawacara) bergeser ke arah penyeragaman yang dibuat pemerintah dalam hal tata cara penyuratan dan pendaftaran awig-awig desa adat di Bali (Bali mawacara). Tujuan penelitian ini adalah untuk mengetahui dan mengkaji tata cara penyuratan dan pendaftaran awig-awig desa adat pasca terbitnya Peraturan Daerah Provinsi Bali Nomor 4 Tahun 2019 Tentang Desa Adat di Bali dikaitkan dengan otonomi yang dimiliki oleh desa adat di Bali. Penelitian ini termasuk ke dalam penelitian kualitatif dengan metode deskriptif menggunakan pendekatan peraturan perundang-undangan dan pendekatan konseptual. Data bersumber dari data sekunder berupa data kepustakaan termasuk peraturan perundang-undangan terkait kemudian dikumpulkan dengan metode kutipan dan dianalisis secara deskriptif dan kemudian disimpulkan. Hasil penelitian menunjukkan terdapatnya pedoman penyuratan dan pendaftaran awig-awig pada Peraturan Daerah Provinsi Bali tentang Desa Adat dan Peraturan Gubernur tentang Pelaksanaan Perda Desa Adat di Bali menunjukkan terjadinya pergeseran dari desa mawacara ke Bali mawacara sehingga dapat mengurangi kadar otonomi yang dimiliki oleh desa adat di Bali, khususnya terkait dalam pembentukan hukum adat terutama pada desa adat Bali Aga yang secara turun-temurun memiliki cara sendiri membentuk hukum adat masing-masing

Kata kunci: penyuratan, pendaftaran, awig-awig desa adat

\section{Procedure For Writing and Registration Awig-Awig Customary Village in Bali (From Desa Mawacara to Bali Mawacara)}

Currently related to one of the traditional rights of customary villages in Bali in managing their own households through the right to establish customary law rules other designations in Bali called awig-awig customary villages have occurred due to the issuance of Bali Provincial Regulation Number 4 of 2019 Concerning Customary Villages in Bali. The shift referred to here, from the initial formation of awig-awig customary villages based on the customary procedures of each customary village (Desa Mawacara) shifted towards uniformity made by the government in terms of the procedures and registration of awig-awig customary villages in Bali (Bali Mawacara). The purpose of this study is to find out and study the procedures for writing and registering awig-awig customary villages after the issuance of the Bali Provincial Regulation Number 4 of 2019 concerning Customary Villages in Bali associated with autonomy held by customary villages in Bali. This research is included in a qualitative research with descriptive method using the statutory approach and conceptual approach. Data sourced from secondary data in the form of library data including related legislation and then collected by the method of quotation and analyzed descriptively and then concluded. The results showed the existence of guidelines for writting and awig-awig registration in the Provincial Regulation of Bali on Customary Villages and the Governor's Regulation on the Implementation of the customary villages in Bali showed a shift from desa mawacara to Bali mawacara so as to reduce the level of autonomy owned by customary villages in Bali especially related to the formation of customary law, especially in the Bali Aga customary village, which for generations has their own way of forming customary law.

Keywords: procedure for writing, registration, awig-awig customary village

Proses Review : 18 - 31 Agustus 2020, Dinyatakan Lolos: 7 September 2020 


\section{PENDAHULUAN}

Provinsi Bali merupakan daerah yang khas. Kekhasan Bali dapat dilihat dari berbagai sudut pandang. Provinsi Bali memiliki 8 (delapan) Kabupaten dan 1 (satu) Kota terdiri dari: "Kabupaten Jembrana, Kabupaten Buleleng, Kabupaten Tabanan, Kabupaten Badung, Kabupaten Gianyar, Kabupaten Klungkung, Kabupaten Bangli, Kabupaten Karangasem dan Kota Denpasar”. Kabupaten dan Kota yang ada tersebut memiliki karakter yang khas pula. Kekhasan Bali dicerminkan dari keberadaan desa yang ada. Berbeda dengan tempat lainnya, Bali memiliki 2 (dua) jenis desa yang memiliki tugas dan fungsi berbeda termasuk kewenangannya. Selain itu terdapat juga kelurahan sebagai wilayah administrasi di Bali. Sampai denga tahun 2020 tercatat terdapat 585 Desa Dinas, 89 Kelurahan dan 1.493 Desa adat yang tersebar di seluruh Bali. Hubungan desa adat dan desa dinas di Bali bukan merupakan hubungan hierarki, melainkan lebih pada hubungan saling melengkapi/ komplementer tanpa ada yang menjadi superior (Adharinalti, 2012: 418) dalam tata hubungan pemerintahan desa. Hubungan saling melengkapi juga berlaku antara Pemerintah Provinsi Bali dengan Desa adat itu sendiri, justru jangan sampai keberadaan Pemerintah Provinsi Bali melalui kebijakan hukum tidak mendukung keberadaan desa adat. Kebijakan hukum seperti ini disebut hukum yang memarginalkan masyarakat adat beserta desa adatnya (Nurjaya, 2012).

Salah satu kekhasan Bali adalah keberadaan dari 1. 493 desa adat di Bali. Jika dilihat dari persebaran jumlah desa adat masing-masing Kabupaten/Kota didapatkan gambaran antara lain: Kabupaten Jembrana terdiri dari 54 desa adat, Kabupaten Buleleng terdiri dari 170 desa adat, Kabupaten Tabanan terdiri dari 349 desa adat, Kabupaten Badung terdiri dari 122 desa adat, Kabupaten Gianyar terdiri dari 273 desa adat, Kabupaten Klungkung terdiri dari 122 desa adat, Kabupaten Bangli terdiri dari 168 desa adat, Kabupaten Karangasem terdiri dari 190 desa adat dan Kota Denpasar terdiri dari 35 desa adat. Begitu banyaknya jumlah desa adat di Bali menjadikan desa adat sebagai labotarium kebudayaan dan adat istiadat yang sangat kompleks. Desa adat di Bali menjadi tempat adanya pembauran unsur-unsur kebudayaan baik berupa nilai-nilai adat istiadat, nilai-nilai ajaran agama, kesenian, tradisi turun temurun termasuk di dalamnya kearifan lokal nenek moyang yang tentunya menjadi potensi yang kuat dari desa adat itu.

Desa adat di Bali tentunya telah memiliki syarat-syarat yang diwajibkan negara untuk mendapatkan pengakuan dan penghormatan. Baik dari sisi adanya warga masyarakat adat (di Bali dikenal istilah krama adat, krama tamiu, dan tamiu), terdapat wilayah teritorial desa adat yang disebut wewidangan desa adat, terdapat pengurus adat disebut dengan prajuru adat, memiliki harta kekayaan desa adat yang disebut padruwen desa adat, memiliki sistem peradilan sendiri dan tentunya yang terpenting ada- lah memiliki hukum adat yang dikenal dengan sebutan $a w$ ig-awig desa adat, termasuk peraturan pelaksananya yang disebut pararem. Semuanya itu berbasis nilai tri hita karana yakni nilai filosofis masyarakat Bali yang menjunjung tinggi adanya keseimbangan antara nilai-nilai Ketuhanan (Parahyangan), nilai-nilai Kemanusiaan (Pawongan), dan nilai-nilai penghormatan terhadap lingkungan hidup (Palemahan) yang berujung pada terciptanya kehidupan harmonis, sejahtera lahir dan bhatin dalam ikatan sosial-religius. Filsafat tri hita karana ini pun digunakan sebagai dasar dalam kehidupan masyarakat Bali, desa adat bahkan tri hita karana sebagai ideologi dari kebijakan dalam bentuk produk hukum daerah di Bali (Dik Roth and Gede Sedana, 2015: 157).

Pengakuan dan penghormatan kepada desa adat sebagai kekhasan dari Bali telah ada dalam ketentuan hukum baik dibuat Pemerintah Pusat maupun dibuat Pemerintah Daerah. Sebagai "kesatuan masyarakat hukum adat" (KMHA), desa adat di Bali mempunyai kewenangan untuk mengelola wilayahnya sendiri. Terkait dengan salah satu dari hak tradisional desa adat di Bali dalam mengurus rumah tangganya sendiri melalui hak untuk membentuk aturan hukum adat sebutan lainnya di Bali disebut awig-awig desa adat inilah yang disebut sebagai selfregulating community. Yakni membuat peraturan untuk komunitasnya sendiri. Pertanyaan muncul apakah dalam fungsi membuat awig-awig sebagai bentuk selfregulating community terdapat acuan yang menjadi pedomannya atau tidak. Walaupun desa adat di Bali mempunyai kewenangan mengatur wilayahnya dengan tata cara sendiri secara umum disebut sebagai otonomi desa adat (desa mawacara), namun sebagai akibat dari diaturnya desa adat di Bali melalui instrumen hukum negara yakni dalam Perda Desa Adat di Bali, maka terdapat beberapa aturan yang berupaya menseragamkan aturan yang berlaku di desa adat di Bali yang dibentuk oleh pemerintah daerah provinsi Bali sebagai pembentuk peraturan daerah keseragaman tersebut salah satunya dalam hal tata cara penyuratan dan pendaftaran awig-awig desa adat di Bali (Bali mawacara). Hal tersebut sebagai latar belakang dilakukannya penelitian yang berjudul Tata Cara Penyuratan dan Pendaftaran Awig-Awig Desa Adat di Bali yang melihat terjadinya pergeseran dari desa mawacara ke bali mawacara. Tata cara penyuratan dan pendaftaran awig-awig desa adat di Bali telah diatur secara normatif dan mendapat pengakuan dan penghormatan sebagai bagian dari kewenangan desa adat berdasarkan ketentuan "Undang-Undang Dasar Negara Republik Indonesia Tahun 1945" (Selanjutnya disebut "UUD NRI Tahun 1945”). "Peraturan Daerah Provinsi Bali Nomor 4 Tahun 2019 tentang Desa Adat di Bali" (Selanjutnya disebut "Perda Desa Adat di Bali"). "Peraturan Gubernur Bali Nomor 4 Tahun 2020 tentang Peraturan Pelaksanaan Peraturan Daerah Nomor 4 Tahun 2019 tentang Desa Adat di Bali" (Selanjutnya disebut "Pergub Pelaksanaan Perda Desa Adat di Bali"). Desa adat di Bali mempunyai kewenangan membuat aturan hukum sendiri dalam bentuk awig-awig desa adat 
merupakan kewenangan kodrati (Sudantra, 2008: 4) yang dibawa sejak lahirnya desa adat tersebut. Hukum Adat atau awig-awig di Bali tidak dapat dipisahkan dengan desa adat itu sendiri, yang bersendikan adat-istiadat di desa adat setempat (Witari, dkk, 2020: 118).

Karya ilmiah ini secara orisional berbeda dengan penelitian yang ada sebelumnya. Ada beberapa karya ilmiah sebagai perbandingan, yaitu penelitian dari A.A Istri Ari Atu Dewi (2014) yang membahas tentang "Eksistensi Otonomi Desa Pakraman dalam Perspektif Pluralisme Hukum". Perbedaan jelas terlihat antara lain, nomenklatur yang digunakan pada penelitian A.A Istri Ari Atu Dewi masih menggunakan nama desa pakraman, sedangkan penelitian tentang Tata Cara Penyuratan dan Pendaftaran Awig-Awig Desa Adat di Bali menggunakan nomenklatur desa adat yang diatur pada Perda Desa Adat di Bali, selain itu substansi penelitian Anak Agung Istri Ari Atu Dewi sifatnya masih general membahas tentang otonomi desa pakraman, sedangkan penelitian ini secara khusus membahas otonomi desa adat dalam bidang membuat aturan hukum khususnya tentang Tata Cara Penyuratan dan Pendaftaran Awig-Awig Desa Adat di Bali yang melihat terjadinya pergeseran dari desa mawacara ke bali mawacara namun tetap dalam bingkai pluralisme hukum. Penelitian selanjutnya, dari Harpin Hadat (2020) yang membahas tentang "Eksistensi Tri Hita Karana dalam Pembentukan Peraturan Hukum di Bali (Perspektif Filsafat Ilmu)". Penelitian Harpin Hadat secara umum membahas sudut pandang ontologi, epistemologi dan aksiologi terkait "Eksistensi Tri Hita Karana dalam Pembentukan Peraturan Hukum di Bali”, sedangkan penelitian yang berjudul Tata Cara Penyuratan dan Pendaftaran Awig-Awig Desa Adat di Bali yang melihat terjadinya pergeseran dari desa mawacara ke bali mawacara ini membahas pengaturan Tata Cara Penyuratan dan Pendaftaran Awig-Awig Desa Adat di Bali yang melihat terjadinya pergeseran dari desa mawacara ke bali mawacara namun tetap dalam bingkai pluralisme hukum.

Tujuan penelitian ini adalah untuk mengetahui dan mengkaji tata cara penyuratan dan pendaftaran awig-awig desa adat pasca terbitnya Peraturan Daerah Provinsi Bali Nomor 4 Tahun 2019 Tentang Desa Adat di Bali dikaitkan dengan otonomi yang dimiliki oleh desa adat di Bali.

\section{METODE PENELITIAN}

Pada penelitian yang berjudul Tata Cara Penyuratan dan Pendaftaran Awig-Awig Desa Adat di Bali yang melihat terjadinya pergeseran dari desa mawacara ke bali mawacara ini dapat dikategorikan ke dalam penelitian kualitatif dengan dasar bahwa beberapa aturan yang dikaji mengandung norma yang kabur (Diantha, 2016: 12). Penelitian ini dalam analisa menggunakan pendekatan peraturan perundang-undangan ("statute approach"), mengkaji konsep hukum yang terkait (“conceptual approach”), serta dianalisa secara hukum ("analytical approach"). Tehnik penelusuran bahan hukum menggunakan tehnik studi dokumen, serta analisis kajian menggunakan analisis kualitatif. Analisa terhadap aturan hukum yang terkait, analisa terhadap konsep-konsep hukum yang ada dan analisa hukum dilakukan terhadap sumber hukum yang ada. Sumber hukum yang dianalisa yakni sumber bahan hukum yang berasal dari peraturan perundang-undangan (sumber hukum primer) maupun sumber bahan hukum penunjang dari literature hukum (sumber hukum sekunder). Bahan hukum primer yang dikaji mulai dari Konstitusi UUD NRI Tahun 1945, Perda Desa Adat di Bali dan Pergub Pelaksanaan Perda Desa Adat di Bali, kemudian konsep-konsep hukum yang ada dianalisis secara hukum dengan bahan hukum sekunder sebagai penunjang analisisnya.

\section{ANALISIS DAN INTEPRETASI DATA}

Pasal 18 B ayat (2) UUD NRI Tahun 1945 menentukan "Negara mengakui dan menghormati kesatuan-kesatuan masyarakat hukum adat beserta hak-hak tradisionalnya sepanjang masih hidup dan sesuai dengan perkembangan masyarakat dan prinsip Negara Kesatuan Republik Indonesia, yang diatur dalam Undang-Undang”. Berdasarkan aturan itu Negara Indonesia melalui instrumen hukum yang ada Negara memberikan pengakuan hukum dan penghormatan secara konstitusi keberadaan "kesatuan masyarakat hukum adat" termasuk di dalamnya kewenangan/hak-hak tradisional yang dimiliki tetapi dengan syarat masih tetap hidup dan memiliki eksistensi sesuai dengan dinamika masyarakat serta sesuai dengan nilai-nilai kesatuan dan persatuan Indonesia. Selain itu dalam Konstitusi UUD NRI Tahun 1945 yang di atur pada "Pasal 28 I ayat (3) disebutkan Identitas budaya dan hak masyarakat tradisional dihormati selaras dengan perkembangan zaman dan peradaban". Demikian juga "Pasal 28I ayat (3) Undang-Undang Dasar Tahun 1945 menegaskan, Identitas budaya dan hak masyarakat tradisional dihormati selaras dengan perkembangan zaman dan peradaban". Terkait dengan keberadaan desa adat sebagai identitas budaya dan sebagai masyarakat tradisional wajib untuk dihormati oleh Negara sesuai dengan dinamika masyarakat dan kebudayaan yang berkembang. Desa adat merupakan kesatuan masyarakat hukum adat yang di dalamnya terdapat masyarakat adat. Masyarakat hukum adat dibagi menjadi masyarakat territorial dan masyarakat geneologis.

Negara mengakui desa adat di Bali melalui instrumen hukum Pemerintah Daerah Provinsi berbentuk Perda Desa Adat di Bali. Pada Secara normatif yuridis definisi desa adat di Bali tunduk pada ketentuan pasal 1 angka 8 yang berbunyi "desa adat adalah kesatuan masyarakat hukum adat di Bali yang memiliki wilayah, kedudukan, susunan asli, hak-hak tradisional, harta kekayaan sendiri, tradisi, tata krama pergaulan hidup masyarakat secara turun temurun dalam ikatan tempat suci (kahyangan tiga atau kahyangan desa), tugas dan kewenangan serta hak mengatur 
dan mengurus rumah tangganya sendiri”. Berangkat mulai dari definisi yuridis normatif dari desa adat di Bali dapat ditarik unsur dari definisi desa adat di Bali yakni:

1. Merupakan suatu kesatuan masyarakat hukum adat di Bali. Makna kesatuan masyarakat hukum adat adalah suatu masyarakat yang tergabung dalam suatu kesatuan sistem hukum yang didasari atas hak kebersamaan.

2. Memiliki wilayah, artinya setiap desa adat di Bali dapat dikatakan sebagai desa adat jika mempunyai daerah sendiri dengan tanda batas tertentu. Tanda batas dapat berupa tanda fisik maupun tanda batas alami.

3. Kedudukan, artinya desa adat memiliki kedudukan hukum sehingga memiliki kewenangan melakukan perbuatan hukum mewakili nama desa adat sendiri.

4. Susunan asli, artinya desa adat memiliki susunan asli baik dari sistem pemerintahan, sistem ekonomi, dll yang telah dilakukan secara turun temurun dan belum terpengaruh oleh budaya luar.

5. Hak-hak tradisional, artinya desa adat memiliki hak yang melekat secara tradisional pada desa adat tersebut, misalnya hak pengelolaan hutan adat, hak pengelolaan laut, hak atas pengelolaan tanah secara tradisional, dll.

6. Harta kekayaan sendiri, artinya desa adat memiliki harta kekayaan baik kekayaan alam, benda maupun kekayaan lainnya yang dikuasai secara komunal oleh desa adat untuk kebutuhan bersama masyarakat adat.

7. Tradisi, artinya desa adat memiliki kebiasaan yang secara turun temurun diwarisi dan dilestarikan baik dari sisi adat, seni dan budaya.

8. Tata krama pergaulan hidup masyarakat secara turun temurun dalam ikatan tempat suci (kahyangan tiga atau kahyangan desa), artinya setiap desa adat terdapat tempat suci yang disebut sebagai kahyangan desa sebagai bukti ikatan bersama.

9. Tugas dan kewenangan serta hak mengatur dan mengurus rumah tangganya sendiri, artinya desa adat memiliki kewenangan untuk mengatur rumah tangganya sendiri termasuk juga mengeluarkan aturan sendiri dalam mengatur wilayahnya".

Desa adat di Bali memiliki kewenangan untuk mengatur wilayahnya sendiri termasuk juga mengeluarkan aturan sendiri dalam mengatur wilayahnya tersebutlah desa adat di Bali memiliki kewenangan untuk menyusun peraturan sendiri yang disebut dengan awig-awig desa adat yang hanya berlaku di wilayahnya masing-masing dengan cara masing-masing (desa mawacara). Hukum adat di Bali secara nyata menjadi bahan baku dari hukum daerah yang berlaku di Bali yang secara khusus hukum daerah yang mengatur tentang kebudayaan yang ada di Bali (Ramstedt , 2014: 1).

Perda Desa Adat di Bali memberikan kewenangan kepada desa adat, secara yuridis diatur pasal 23 dimana di atur "kewenangan desa adat meliputi kewenangan berdasarkan hak asal usul dan kewenangan lokal berskala Desa
Adat". Kemudian, "kewenangan desa adat di Bali yang berdasarkan atas hak asal-usul diatur pada pasal 24 yang menyebutkan antara lain":

a. pembentukan awig-awig, pararem, dan peraturan adat lainnya;

b. penetapan perencanaan pembangunan desa adat;

c. penetapan Anggaran Pendapatan dan Belanja Desa Adat;

d. pelaksanaan pemerintahan berdasarkan susunan asli;

e. pengembangan dan pelestarian nilai adat, agama, tradisi, seni dan budaya serta kearifan lokal;

f. pengelolaan wewidangan dan tanah padruwen desa adat;

g. pengelolaan padruwen desa adat;

h. pengembangan kehidupan hukum adat sesuai dengan asas Bali Mawacara dan Desa Mawacara;

i. penetapan sistem organisasi dan pranata hukum adat;

j. turut serta dalam penentuan keputusan dan pelaksanaan pembangunan yang ada di wewidangan desa adat;

k. pemeliharaan ketenteraman dan ketertiban krama di desa adat;

1. penyelenggaraan sidang perdamaian perkara adat/ wicara adat yang bersifat keperdataan; dan

m. penyelesaian perkara adat/wicara berdasarkan hukum adat. Secara umum pelaksanaan kewenangan desa adat tersebut agar memperhatikan keseimbangan antara ketertiban, ketenteraman, kesejahteraan, kebahagiaan, dan kedamaian krama desa adat"

Dimana secara rinci kewenangan desa adat diatur dalam awig-awig desa adat masing-masing. Maka berdasarkan ketentuan pada pasal 24 desa adat berdasarkan hak asal usul memiliki kewenangan dalam penyusunan dan pendaftaran awig-awig, pararem, dan peraturan adat lainnya. Lahirnya Perda Desa Adat di Bali sebagai bentuk upaya dalam melestarikan kebudayaan yang ada di Bali dalam wacana ajeg Bali yang selalu dikampanyekan baik oleh pemerintah maupun oleh masyarakat umum. Ajeg Bali sebagai suatu jargon dalam upaya melestarikan kebudayaan Bali termasuk desa adat di dalamnya. Sebagai sebuah gerakan kebudayaan ajeg Bali merupakan suatu bentuk hasil dari politik desentralisasi secara lokal di Bali (Tamatea, 2011: 155). Ajeg Bali sebagai implikasi dari lahirnya otonomi daerah (Allen and Palermo, 2005: 239) yang dilaksanakan oleh Pemerintah Provinsi Bali, termasuk di dalamnya membuat produk hukum daerah yang berisi kekhasan daerah Provinsi Bali.

Bagian terpenting pelaksanaan otonomi desa adat adalah penyuratan/ penulisan awig-awig desa adat. Beberapa pengertian yang terkandung dalam penulisan awig-awig, antara lain (Sudantra dan Windia, 2012: 89):

1. Penulisan awig-awig dalam pengertian menuliskan awig-awig yang sebelumnya tidak tertulis.

2. Penulisan awig-awig dalam pengertian melakukan perbaikan dari sisi bahasa dan tata cara penulisan aw- 
ig-awig yang ada sudah di tulis sebelumnya.

3. Penulisan awig-awig dalam pengertian merubah aturan-aturan yang ada pada awig-awig tertulis sebelumnya agar lebih sesuai dengan perkembangan zaman

4. Penulisan awig-awig dalam pengertian menyusun buku awig-awig tertulis.

Kewenangan desa adat yang begitu besar diberikan oleh Perda Desa Adat di Bali sebagai bentuk upaya intervensi positif negara dalam artian Pemerintah Daerah Provinsi Bali untuk memberikan kepastian hukum atas keberadaan desa adat di Bali. Selain itu disisi lain, adanya kebangkitan adat (desa adat) di Bali mulai melakukan intervensi terhadap segala kebijakan hukum (Jiwa Utama, 2020: 17) yang ada di Bali sebagai sesuatu yang sulit dihindari. Inilah yang disebut dengan formalisasi desa adat di Bali. Kebijakan produk hukum daerah berupa Perda Desa adat di Bali yang memberikan kepastian hukum atas keberadaan desa adat di Bali merupakan kebijakan yang pro adat. Kebijakan pro adat adalah kebijakan hukum yang mendukung keberadaan desa adat termasuk kewenangannya (Vel and Makambombu, 2019: 435).

Berdasarkan yuridis-formal definisi dari awig-awig desa adat di atur dalam Perda Desa Adat di Bali khususnya pasal 1 angka 29 berbunyi "awig-awig adalah aturan yang dibuat oleh desa adat dan/atau banjar adat yang berlaku bagi krama desa adat, krama tamiu, dan tamiu”. Senada dengan ketentuan Pasal 1 angka 13 Pergub Pelaksanaan Perda Desa Adat di Bali menyatakan "awig-awig adalah aturan yang dibuat oleh desa Adat dan/atau banjar adat yang berlaku bagi krama desa adat, krama tamiu, dan tamiu”. Berdasarkan aturan hukum itu terdapat beberapa unsur terkait definisi normatif dari awig-awig, yakni, (1) awig-awig merupakan peraturan bermuatan adat disusun desa adat dan/ atau banjar adat, dan (2) berlaku bagi kra$m a$ desa adat ("masyarakat adat yang beragama Hindu yang 'mipil' dan tercatat/ terigestrasi sebagai masyarakat adat di desa adat tempat setempat"), berlaku bagi krama tamiu ("masyarakat adat yang beragama Hindu yang 'tidak mipil', melainkan hanya tercatat/ terigestrasi sebagai masyarakat adat di desa adat tempat setempat"), dan tamiu ("tidak tergolong krama adat maupun krama tamiu yang bertempat tinggal di wilayah desa adat untuk sementara atau bertempat tinggal dan tercatat di desa adat setempat").

Pada pasal 13 Perda Desa Adat di Bali pada ayat (1) berbunyi "Setiap desa adat memiliki awig-awig". Selanjutnya pada ayat (2) berbunyi "awig-awig sebagaimana dimaksud pada ayat (1) terdiri atas: a. Awig-awig tersurat; dan b. Awig-awig yang belum tersurat". Selanjutnya ayat (3) berbunyi "awig-awig tersurat dan yang belum tersurat mempunyai kekuatan hukum yang sama". Pada ayat (4) berbunyi "setiap desa adat berkewajiban menyuratkan awig-awig". Ayat (5) berbunyi "ketentuan mengenai tata cara penyuratan awig-awig sebagaimana dimaksud pada ayat (4) diatur lebih lanjut dalam Peraturan Gubernur".
Selanjutnya pengaturan awig-awig khususnya dalam hal pendaftaran awig-awig berdasarkan Pasal 17 ayat (1) berbunyi "awig-awig tersurat desa adat didaftarkan oleh prajuru desa adat ke perangkat daerah Provinsi yang membidangi urusan desa adat". Selanjutnya ayat (2) berbunyi "ketentuan lebih lanjut mengenai tata cara pendaftaran $a w$ ig-awig sebagaimana dimaksud pada ayat (1) diatur dalam Peraturan Gubernur".

Berkaitan dengan ketentuan pasal 13 ayat (5) dan pasal 17 ayat (2) tentang ketentuan tata cara penyuratan dan pendaftaran awig-awig diatur dalam Peraturan Gubernur, maka pada tanggal 6 Maret 2020 telah disahkan dan diundangkan Pergub Pelaksanaan Perda Desa Adat di Bali. Diatur dalam Bab II tentang Tata Cara Penyuratan dan Pendaftaran Awig-awig terutama diatur pada ketentuan pasal 3 sampai dengan pasal 9.

Berkaitan dengan tata cara penyuratan awig-awig diatur dalam Pasal 3 Pergub Pelaksanaan Perda Desa Adat di Bali pada ayat (1) berbunyi setiap Desa Adat berkewajiban menyuratkan Awig-awig. Kemudian pada ayat (2) berbunyi penyuratan awig-awig paling sedikit mengatur ketentuan mengenai: a). "aran miwah wewidangan”; b). "pamikukuh miwah patitis"; c). "sukreta tata parahyangan"; d). "sukreta tata pawongan"; e). "sukreta tata palemahan"; f). "bhaya, wicara, miwah pamidanda"; g). Perubahan "awig-awig (nguwah-nguwuhin)"; dan h). "pamuput". Pada ayat (3) menyatakan bahwa "penyuratan awig-awig desa adat disusun dalam Bahasa Bali dan Bahasa Indonesia". Kemudian pada ayat (4) menyatakan "Bahasa Bali menggunakan aksara Bali dan huruf Latin". Pada ayat (5) menyatakan "Bahasa Indonesia menggunakan huruf Latin".

Selanjutnya pada Pasal 4 Pergub Pelaksanaan Perda Desa Adat di Bali pada ayat (1) berbunyi "awig-awig desa adat harus disusun berdasarkan pedoman penyuratan awig-awig desa adat." Kemudian diatur ayat (2) yang berbunyi "pedoman disusun oleh Majelis Desa Adat/ MDA Provinsi difasilitasi oleh Dinas". Berkaitan dengan tata cara pendaftaran awig-awig Pasal 5 ayat (1) berbunyi "prajuru desa adat mendaftarkan awig-awig desa adat kepada Dinas". Pada ayat (2) berbunyi "awig-awig desa adat yang didaftarkan merupakan awig-awig desa adat yang telah disahkan dalam paruman desa adat". Kemudian pada ayat (3) berbunyi "pengesahan dituangkan dalam berita acara".

Pendaftaran awig-awig desa adat berdasarkan ketentuan pasal 6 Pergub pelaksanaan Perda Desa Adat di Bali dilengkapi dengan: “(a) Surat permohonan pendaftaran awig-awig dari Bendesa Adat dan/atau Panyarikan; (b) Awig-awig dalam bentuk tercetak (hard copy) rangkap 3 (tiga) dan rekaman elektronik (softcopy); (c) Berita acara pengesahan awig-awig desa adat; dan (d) Surat keterangan MDA Provinsi yang menyatakan bahwa awig-awig telah disusun dan ditulis sesuai dengan pedoman penyuratan 
awig-awig desa adat". Selanjutnya menurut ketentuan Pasal 7 berbunyi "Dinas menerima dan mencatat dokumen pendaftaran awig-awig desa adat".

Ketentuan Pasal 8 Pergub Pelaksanaan Perda Desa Adat di Bali ayat (1) menyatakan bahwa "dalam hal pendaftaran awig-awig desa adat telah memenuhi persyaratan Dinas memberikan nomor registrasi". Nomor registrasi dicantumkan pada halaman terakhir bagian bawah awig-awig desa adat sebagaimana ketentuan ayat (2). Selanjutnya, pada ayat (3) Nomor registrasi terdiri atas: “a) Kode A menunjukkan awig-awig. b) Nomor urut registrasi dengan angka empat digit; c) Kode desa adat dengan angka empat digit; d) Kode Kecamatan dengan angka tiga digit; e) Kode Kabupaten/Kota dengan angka dua digit; f) Kode dinas dengan singkatan DPMA (Dinas Pemajuan Masyarakat Adat); dan g) Tahun pengeluaran nomor registrasi". Ketentuan selanjutnya terkait nomor registrasi di atur pada ayat (4) menyatakan "Nomor registrasi ditulis dengan format kode awig-awig/nomor urut registrasi/kode Desa Adat/kode Kecamatan/kode Kabupaten/Kota/kode Dinas/tahun pengeluaran nomor registrasi”. Pada ayat (5) menyatakan "Kode mengacu pada Lampiran I yang merupakan bagian tidak terpisahkan dari Peraturan Gubernur ini". Pada ayat (6) menyatakan bahwa "Nomor registrasi diberikan paling lambat 9 (sembilan) hari kerja sejak pendaftaran diterima".

Selain terkait dengan penyuratan dan pendaftaran awig-awig, terdapat pula pembinaan awig-awig, sesuai ketentuan Pasal 9 ayat (1) berbunyi "Dinas melakukan pembinaan awig-awig". Kemudian pada ayat (2) berbunyi "dalam melakukan pembinaan awig-awig Dinas membentuk Tim yang terdiri dari unsur: (a) Dinas; (b) Perangkat Daerah terkait; (c) Majelis Desa Adat di semua tingkatan; (d) Parisada Hindu Dharma Indonesia; dan (e) Perguruan Tinggi".

Menarik untuk dikaji terkait dengan ketentuan pasal 3 Pergub Pelaksanaan Perda Desa Adat di Bali khususnya pada ayat (1) berbunyi "setiap desa adat berkewajiban menyuratkan awig-awig, maka ke depan di Bali semua desa adat memiliki kewajiban untuk menyuratkan $a w$ ig-awig desa adat masing-masing". Jika ditelusuri awig-awig tertulis maupun tidak tertulis masing-masing mempunyai keunggulan dan kelemahan.

Awig-awig desa adat dalam bentuk tertulis mempunyai keunggulan mengarah pada jaminan adanya kepastian hukum, lebih mudah dipelajari dan dipahami, dan lebih mudah dilaksanakan. Sedangkan kelemahan dari awig-awig tertulis antara lain, kaku sehingga sulit disesuaikan dengan perkembangan dan relatif lebih sulit memberikan jaminan pemenuhan keadilan bagi masyarakat yang ada pada desa adat berlakunya awig-awig tersebut. Sebaliknya, awig-awig yang memiliki bentuk tidak dituliskan memiliki keunggulan antara lain: menjamin keterbukaan atas penafsiran dan perubahan tidak rumit dalam melakukan penyesuaian terhadap perkembangan jaman serta lebih memberikan jaminan terpenuhinya nilai-nilai keadilan yang diharapkan masyarakat yang bertempat tinggal pada desa adat tempat berlakunya awig-awig tersebut. Sedangkan kekurangan dari awig-awig berbentuk tidak tertulis, antara lain: tidak sepenuhnya dapat menjamin nilai-nilai kepastian hukum, tidak mudah untuk dipelajari dan dimengerti karena tidak tertulis, tidak mudah diimplementasikan terutama oleh prajuru adat yang meneruskan estafet kepemimpinan di desa adat serta sangat dipengaruhi pada nilai-nilai moral prajuru dan warga masyarakat desa adat secara umum. Prinsip kepastian hukum merupakan prinsip dimana kejelasan aturan hukum menjadi prioritas. Setiap masyarakat mempunyai Awig-awig desa adat, yaitu peraturan dan ketentuan dasar yang menjadi pedoman perilaku bagi seluruh krama desa adat di dalam kehidupan bersama.

Secara umum proses penulisan awig-awig terdapat 4 tahapan, antara lain (Sudantra dan Windia, 2012: 89):

1. Tahapan awal persiapan (didahului mengadakan paruman desa dengan jadwal perencanaan penulisan/ revisi awig-awig, jika disetujui dilanjutkan dengan pembentukan panitia penulisan awig-awig, setelah terbentuk panitia penulisan awig-awig melaksanakan matur piuning di khayangan desa, selanjutnya dibentuk panitia kerja dibentuk sesuai dengan kebutuhan serta membentuk kalender kegiatan ).

2. Tahapan Penulisan Awig-awig (Melakukan evaluasi terhadap awig-awig yang ada, membandingkan dengan desa adat yang lainnya, merumuskan kesepakatan-kesepakatan, mengundang ahli dalam bidang tertentu yang dibutuhkan dan melakukan kordinasi dengan pemerintah Kabupaten/ Kota khususnya di bagian hukum dan dengan Majelis Desa Adat, sampai tersusunya draft awal awig-awig)

3. Tahapan Sosialisasi Rancangan Awig-awig (Draft awal awig-awig yang telah tersusun disosialisasikan kepada krama desa adat untuk mendapatkan masukan-masukan, kemudian masukan tersebut dimasukan kedalam draft oleh panitia sehingga tersusun draft akhir rancangan awig-awig desa adat).

4. Tahapan Penyelesaian Penulisan Awig-awig (Melakukan kegiatan nyobyahang/ mensosialisasikan isi awig-awig untuk mendapatkan persetujuan krama desa adat, setalah disetujui dalam paruman desa adat selanjutnya dilakukan proses penandatanganan oleh Bendesa adat dan disaksikan pihak terkait misalnya Majelis Desa Adat. Selanjutnya, awig-awig ditandatangani oleh Bupati/Walikota sebagai bentuk formal pemerintah telah mengakui dan menghormati awig-awig sebagai bentuk pengukuhan dari negara. Proses terakhir dilakukan pengukuhan secara niskala melalui upacara pemelaspasan awig-awig. Dan tahapan akhirnya adalah pembubaran panitia penulisan awig-awig).

Selanjutnya, jika melihat ketentuan pasal 54 ayat (1) ber- 
bunyi "awig-awig desa adat dan pararem yang sudah ada sebelum Peraturan Gubernur ini diundangkan tetap berlaku sampai dengan terbentuknya awig-awig desa adat dan pararem sesuai dengan Peraturan Gubernur ini”. Selanjutnya pada ayat (2) berbunyi "penyesuaian awig-awig dan pararem paling lama dilaksanakan 2 (dua) tahun sejak Peraturan Gubernur ini diundangkan pada tanggal 6 Maret 2020". Muncul pertanyaan bagaimana jika penyesuaian awig-awig dan pararem paling lama dilaksanakan 2 (dua) tahun sejak Peraturan Gubernur ini diundangkan tidak ada penyesuaian yang dilakukan oleh desa adat terhadap awig-awig dan pararem apakah terdapat konsekuensi hukumnya atau tidak. Ini tidak terdapat pengaturannya secara tegas dalam Peraturan Gubernur tersebut. Sehingga tidak ada kewajiban dari desa adat melakukan penyesuaian $a w$ ig-awig dan pararem. Misalnya, juga awig-awig desa adat Tenganan Pagringsingan yang dibuat salinannya berdasarkan ingatan masyarakat karena naskah asli awig-awig desa adat telah terbakar pada tahun 1841 disempurnakan lagi pada tahun 1925 yang struktur penulisannya tidak mengikuti pedoman yang ada. Perlu diketahui bahwa awig-awig desa adat Tenganan Pagringsingan menggunakan model penulisan 2 (dua) kolom dimana kolom kiri menggunakan bahasa Bali dan sebelah kanan menggunakan bahasa Indonesia dengan ejaan lama terdiri dari 61 pasal.

Menarik juga menjadi temuan penelitian bahwa terdapatnya pedoman penyuratan dan pendaftaran awig-awig pada ketentuan dalam Pergub Pelaksanaan Perda Desa Adat di Bali menunjukkan terjadinya pergeseran dari desa mawacara ke Bali mawacara dalam penyusunan awig-awig masing-masing desa adat (apalagi terdapat 3 (tiga) tipologi desa adat, yakni desa adat Bali Aga, Bali Apanaga dan Bali Anyar). Padahal jika ditelisik desa adat di Bali mempunyai tipologi hukum berbasis "desa, kala, patra, desa mawacara". Pengertian dari "Desa Mawacara" merupakan aturan hukum bermuatan adat dimana pemberlakuannya hanya di Desa Adat setempat, baik secara tertulis maupun secara tidak tertulis. Sedangkan pengertian "Bali Mawacara" merupakan kesamaan hukum yang bermuatan materi adat, pemberlakuannya di seluruh Bali secara seragam, baik secara tertulis maupun secara tidak tertulis.

Secara umum, baik Perda Desa Adat di Bali dan Pergub Pelaksanaan Perda Desa Adat di Bali mengandung prinsip-prinsip pluralisme hukum. Prinsip pluralisme hukum dapat mendegradasi adanya konflik antara paham yang menjunjung tinggi nilai-nilai keseragaman atau "universalisme" dengan nilai-nilai yang lebih mengarah keberagaman atau "lokalisme" akibatnya dapat mencapai suatu kestabilan umum di masyarakat (D.Fry, 2014: 1). Prinsip-prinsip pluralisme hukum juga memiliki ciri berisi tidak hanya aturan hukum negara melainkan terdapat norma hukum lainnya serta aturan, prinsip pluralisme ini berangkat adanya keberagaman hukum dalam masyarakat yang tidak dapat dihindarkan (Twinning, 2010: 488). Pen- gaturan Tata Cara Penyuratan dan Pendaftaran Awig-Awig Desa Adat di Bali termasuk ke dalam jenis prinsip pluralisme yang didominasi oleh hukum negara (state legal pluralism) (Woodman, 2005: 152), sebutan lainnya sebagai pluralisme hukum bersifat tidak kuat/ lemah (weak legal pluralism) (Griffiths, 2005: 74).

Kategori prinsip pluralisme hukum negara terjadi apabila dalam suatu produk hukum lebih dominan pengaturan dari norma hukum Negara namun di sisi lain juga mengadopsi norma hukum lainnya seperti norma agama dan hukum adat. Prinsip pluralisme hukum di Indonesia tidak terlepas dari fakta bahwa Indonesia merupakan sebuah negara yang memiliki keberagaman baik dari sisi keberagaman suku, agama, adat istiadat, maupun keberagaman daerah. Adanya keberagaman tersebut harus mampu diakomodasi oleh prinsip hukum yang dapat mengadopsi fakta keberagaman Indonesia tersebut. Produk hukum yang mengandung prinsip-prinsip pluralisme hukum sangat diharapkan mampu menjadi jembatan keberagaman khususnya dalam berhukum di Indonesia sebagai hukum yang dapat berjalan di tengah-tengah kepentingan yang ada. Norma politik itu tidak lain adalah prinsip Negara hukum Indonesia berdasarkan atas Pancasila.

Tamanaha (2007) memberikan pandangan mengenai prinsip-prinsip pluralisme hukum yang di belahan dunia manapun secara umum dapat ditemukan di segala tingkatan hukum, berangkat dari hukum yang berlaku di daerah, hukum yang berlaku secara nasional, maupun hukum yang berlaku secara transnasional bahkan hukum yang berlaku secara internasional. Prinsip pluralisme hukum berusaha membongkar dan menepis anggapan bahwa hukum satu-satunya adalah hukum yang dibuat oleh negara secara formal, tidak ada hukum selain hukum negara. Padahal diketahui bersama di sisi lain terdapat hukum yang lainnya (Perez, 2011: 1). Pluralisme hukum secara praktis dapat menjadi hukum yang mampu menjadi prinsip hukum yang menetralisir adanya pertentangan hukum secara yuridis-normatif (Berman, 2007: 1155). Untuk menetapkan prinsip dan atmosfer pluralisme dalam kebijakan hukum harus mampu memberikan ruang kepada hukum yang dianut masyarakat adat yang secara nyata telah hidup di negara ini, termasuk di Bali (Nurjaya, 2015: 75).

Terdapatnya unsur hukum negara yakni diwakili oleh produk hukum daerah dalam bentuk Perda Desa Adat di Bali dan Pergub Pelaksanaan Perda Desa Adat di Bali, prinsip-prinsip serta kaedah dalam ajaran agama Hindu dan moral secara formal diwakili oleh nilai-nilai filsafat tri hita karana kemudian di padukan dengan konsep nilai luhur sad kerthi, dan sebagai norma hukum adat diwakili oleh hukum adat desa adat di Bali (awig-awig desa adat, perarem dan peraturan desa adat lainnya) yang tertuang dalam Perda Desa Adat di Bali dan Pergub Pelaksanaan Perda Desa Adat di Bali sebagai bentuk pluralisme hukum di Bali dalam penyuratan dan pendaftaran awig-awig di Bali. 


\section{SIMPULAN}

Terkait dengan salah satu dari hak tradisional desa adat di Bali dalam mengurus rumah tangganya sendiri melalui hak untuk membentuk hukum adat atau dikenal dengan nama awig-awig desa adat inilah yang disebut sebagai selfregulating community. Terdapat pengakuan negara terhadap desa adat di Bali baik dari sisi konstitusi, undang-undang, maupun dalam bentuk peraturan daerah yang berlaku di Bali. pedoman penyuratan dan pendaftaran awig-awig yang tertuang dalam Pergub Pelaksanaan Perda Desa Adat di Bali menunjukkan terjadinya pergeseran dari desa mawacara ke Bali mawacara dalam penyusunan awig-awig masing-masing desa adat. Pada awalnya penyusunan awig-awig masing-masing desa adat disesuaikan dengan keadaan masing-masing desa (desa mawacara), namun saat ini di Bali telah terdapat upaya penyeragaman penyuratan dan pendaftaran awig-awig desa adat yang di atur dalam Pergub Pelaksanaan Perda Desa Adat di Bali yang mengarah ada satu hukum tentang penyuratan dan pendaftaran awig-awig desa adat di Bali (bali mawacara). Secara umum, baik Perda Desa Adat di Bali dan Pergub Pelaksanaan Perda Desa Adat di Bali mengandung pluralisme hukum. Ke depan penyesuaian awig-awig dan pararem "paling lama dilaksanakan 2 (dua) tahun sejak Peraturan Gubernur ini diundangkan" tidak ada penyesuaian yang dilakukan oleh desa adat terhadap awig-awig dan Pararem tidak terdapat konsekuensi hukumnya. Ini tidak terdapat pengaturannya secara tegas dalam Peraturan Gubernur tersebut. Sehingga tidak ada kewajiban dari desa adat melakukan penyesuaian awig-awig dan pararem.

\section{DAFTAR RUJUKAN}

Adharinalti. (2012). Eksistensi Hukum Adat dalam Penyelenggaraan Pemerintahan Desa di Bali. Jurnal Rechtvinding, Media Pembinaan Hukum Nasional, 1 (3).

Allen, Pamela and Carmencita Palermo. (2005). Ajeg Bali: Multiple Meanings, Diverse Agendas. Indonesia and The Malay World Journal, 33 (97), Doi: 10.1080/ 13639810500449115.

Berman, Paul Schiff. (2007). Global Legal Pluralism. Southern California Review. Princeton Law and Public Affairs Working. (80).

D.Fry, James. (2014). Pluralism, Religion, and Moral Fairness of International Law. Oxford Journal: Law and Religion. (3).

Dewi, Anak Agung Istri Ari Atu. (2014). Eksistensi Otonomi Desa Pakraman dalam Perspektif Pluralisme Hukum. Jurnal Magister Hukum Udayana, 7 (3). https://doi. org/10.24843/JMHU.2014.v03.i03.

Diantha, I Made Pasek. (2016), Metodologi Penelitian
Hukum Normatif dalam Justifikasi Teori Hukum, Prenada Media, Bandung.

Griffiths, John. (2005). “Memahami Pluralisme Hukum, Sebuah Deskripsi Konseptual dalam Tim HuMa, eds., Pluralisme Hukum: Sebuah Pendekatan Interdisiplin, (Jakarta: Penerbit (HuMa).

Hardat, Harpin. (2020). Eksistensi Tri Hita Karana dalam Pembentukan Peraturan Hukum di Bali (Perspektif Filsafat Ilmu). Jurnal Magister Hukum Udayana, 9 (1). https:// doi.org/10.24843/JMHU.2020.v09.i01.

Nurjaya, I Nyoman. (2012). State Law in Multiculturall Country of Indonesia: Toward A Just and Equitable State in Legal Anthropology Point of View. US-China Law Review, 9 (1).

Nurjaya, I Nyoman. (2015). Constitutional and Legal Recognition Over Traditional Adat Community Within The Multicultural Country of Indonesia: Is It A Genuine or Pseudo Recognition?. Perspektif, XX (2).

Perez, Oren. (2011). Legal Pluralism. The Oxford Encyclopedia of American Political and Legal History.

Ramstedt, Martin. (2014). Discordant Temporalities in Bali's New Village Jurisdictions. The Journal of Legal Pluralism and Unofficial Law, 46 (1). https://doi.org/10.10 80/07329113.2014.893722.

Roth, Dik and Gede Sedana. (2015). Reframing Tri Hita Karana: From "Balinese Culture" to Politics.

The Asia Pacific Journal of Anthropology, 16 (2), 157-17. Doi: 10.1080/ 14442213.2014.994674.

Sudantra, I Ketut. (2008). Pengaturan Penduduk Pendatang dalam Awig-Awig Desa Pakraman. Piramida, 4 (1).

Sudantra, I Ketut dan Wayan P. Windia. (2012), Sesana Prajuru Desa (Tata Laksana Pimpinan Desa Adat di Bali), Udayana University Press dan Bali Shanti, Denpasar.

Tamanaha, Brian Z. (2007). Understanding Legal Pluralism: Past to Present, Local to Global. Sydney Law Review. (29).

Tamatea, Laurence. (2011). Ajeg Bali Discourse: Globalisation, Fear adn Othering. Asian Ethnicity, 12 (2), 155 177. Doi: 10.1080/ 14631369.2011.571835.

Twinning, William. (2010). Normative and Legal Pluralism: A Global Perspective. Duke Journal of Comparative and International Law. 20 (473).

Utama, Tody Sasmitha Jiwa. (2020). Impediments to Establishing Adat Villages: A Socio-Legal Examination of the 
Indonesian Village Law. The Asia Pacific Journal of Anthropology, 21 (1), Doi: 10.1080/ 14442213.2019.1670240.

Woodman, Gordon R. (2005). 'Mungkinkah Membuat Peta Hukum?' dalam Tim HuMa, eds., Pluralisme Hukum: Sebuah Pendekatan Interdisiplin. Jakarta: Penerbit (HuMa).

Witari, Made Ratna, Paramadhyaksa, I.N dan Yudantini, N.M (2020). Variasi Pemanfaatan Tanah Pelaba Pura Dalem di Desa Adat Kesiman, Denpasar. Mudra Jurnal Seni dan Budaya,. 35 (1). Doi;10.31091/mudra. v35i1.1030.

Vel, Jacqueline and Stepanus Makambombu. (2019). Strategic Framing of Adat in Land-Acquisition Politics in East Sumba. The Asia Pacific Journal of Anthropology, 20 (5), Doi; 10.1080/ 14442213.2019.1670239. 